\title{
IJ DSES S
}

\section{Sosyal Bilgilerde Argümantasyon Tabanlı Öğrenme Sürecinin Öğrenci Başarı ve Tutumlarına Etkisi}

The Effect of Argumentation Based Learning Process on Student Academic Achievement and Attitudes in Social Studies

\author{
Ferya Aksoy Serttaş \\ Akdeniz Üniversitesi \\ Eğitim Fakültesi
}

ferya1994ak@gmail.com

ORCID ID: 0000-0003-1020-7972

\section{Hilmi Demirkaya}

Prof. Dr.

Akdeniz Üniversitesi

Eğitim Fakültesi

hilmi.demirkaya@gmail.com;

ORCID ID: 0000-0002-4456-580X

\section{Makale Bilgisi / Article Information}

\author{
Makale Türü / Article Type : Araştırma Makalesi \\ Geliş Tarihi / Received : 27 Mayıs 2021 \\ Kabul Tarihi / Accepted : 15 Haziran 2021 \\ Yayın Tarihi / Published : 20 Haziran 2021 \\ DOI Number : 10.20860/ijoses.943717
}

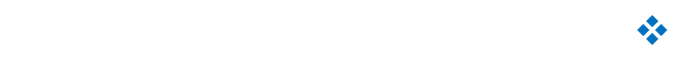

Kaynak Gösterme / Citation

Serttaş, F. A. \& Demirkaya, H. “Sosyal Bilgilerde Argümantasyon Tabanlı Öğrenme Sürecinin Öğrenci Başarı ve Tutumlarına Etkisi ". Uluslararası Sosyal ve Eğitim Bilimleri Dergisi, 15 (2021): 40-54.
\end{abstract}




\title{
Sosyal Bilgilerde Argümantasyon Tabanlı Öğrenme Sürecinin Öğrenci Başarı ve Tutumlarına Etkisi*
}

\author{
The Effect of Argumentation Based Learning Process on Student Academic Achievement and Attitudes in \\ Social Studies
}

Ferya Aksoy Serttaş \& Hilmi Demirkaya

\begin{abstract}
Öz
Bu araştırmanın amacı, sosyal bilgiler eğitiminde 'Bilim, Teknoloji ve Toplum Ünitesi'nin öğrenilmesinde argümantasyon tabanlı öğrenme sürecinin etkilerini incelemektir. Araştırma öntestsontest kontrol gruplu yarı-deneysel desene uygun olarak tasarlanmıştır. Araştırmada nicel yöntemin yanında nitel görüşme yöntemi de kullanıımıştır. Araştırmanın evrenini Antalya ili kepez ilçesinde bulunan Ersoy Ortaokulu'nda öğrenim gören 7. sınıf öğrencileri oluşturmaktadır. Araştırmanın örneklemini ise deney (31) ve kontrol (31) grubunda olmak üzere toplam 62 öğrenci oluşturmaktadır. Uygulama kapsamında yedinci sınıf sosyal bilgiler dersi ünitelerinden "Bilim, Tekonoloji ve Toplum" ünitesi, deney grubuna araştırmacı tarafından hazırlanan Argümantasyon Tabanlı Öğretim Yöntemi yoluyla, kontrol grubuna ise öğretim programına uygun şekilde anlatılmıştır. Uygulama sonucunda elde edilen veriler SPSS 23.00 üzerinde betimsel istatistik, Mann Withney U-testi ve Wilcoxon İşaretli Sıralar Testi teknikleri yoluyla analiz edilerek yorumlanmıştır. Araştırma verilerinin analizi sonucunda Sosyal Bilgiler dersinde Argümantasyon Tabanlı Öğretim Yöntemi kullanımının öğrencilerin başarısı ve tutumları üzerinde anlamlı düzeyde bir etkisinin olduğu sonucuna ulaşılmıştır. Araştırmada ortaya çıkan sonuçlar, ilgili literatürün sonuçları ile karşılaştırılmıştır.
\end{abstract}

Anahtar Kelimeler: Sosyal Bilgiler, Ortaokul, Argümantasyon Temelli Öğrenme Yöntemi, Yarı Deneysel Desen, Tutum

\section{Abstract}

The purpose of this research is to examine the effects of the argumentation-based learning process on learning the "Science, Technology and Society Unit" in social studies education. The research was designed in accordance with the pretest-posttest control group quasi-experimental design. In addition to the quantitative method, qualitative interview method was also used in the study. The universe of the research consists of 7th grade students studying in Ersoy Middle School located in Antalya province Kepez district. The sample of the study, on the other hand, consists of 62 students in the experimental (31) and control (31) groups. Within the scope of the application, the unit of "Science, Technology and Society", one of the seventh grade social studies lesson units, was explained to the experimental group through the argumentation-based teaching method prepared by the researchers, and to the control group in accordance with the curriculum. The data obtained as a result of the application were analyzed and interpreted on SPSS 23.00 using descriptive statistics, Mann Withney U-test and Wilcoxon Signed Ranks Test. As a result of the analysis of the research data, it was concluded that the use of argumentation-based teaching method in social studies course has a significant effect on students' achievement and attitudes. The results of the study were compared with the results of the relevant literature.

Keywords: Social Studies, Middle School, Argümentation Based Learning Method, Quasi Experimental Design, Attitude

* Bu makale 2019 yılında Akdeniz Üniversitesi Eğitim Bilimleri Enstitüsü Türkçe ve Sosyal Bilimler Anabilim Dalı’nda sunulan "Sosyal Bilgiler Eğitiminde Bilim, Teknoloji ve Toplum Ünitesinin Öğretiminde Argümantasyon Tabanlı Öğrenme Sürecinin Etkisi" adlı yüksek lisans tezinden türetilmiştir. 


\section{Extended Summary}

\section{Purpose and Significance:}

Argumentation is a scientific debate based on proving or refuting the facts and claims. Argumentation method emerges as an effective method in increasing students' conceptual learning and academic achievement as well as enabling students to think critically. Therefore, it is thought that the argumentation method of the study may be important in increasing student achievement in social studies education and in developing skills to express their thoughts in front of a community. It is thought that this research can guide social studies teachers and guide future researchers as it is the first research to include Argumentation Based Learning activities in the Science Technology and Society Unit of the Social Studies Course at the middle school level. In addition, when we look at the previous studies on the argumentation method, it is noteworthy that a lot of research has been done on the science lesson. When we look at the field of social studies education on the subject, there are very few studies on the use of argumentation method. This research is important for purposes such as eliminating this deficiency in the field of social studies education.

\section{Methodology:}

This research is designed in accordance with the quantitative research method. In the research, a quasiexperimental design with pretest-posttest comparison groups was used. Pre-test-post-test comparison group design is the measurement of participants before and after the experimental study regarding the dependent variable (Karasar, 1999, p.86). Data collection and analysis of the last sub-problem of the study was carried out in accordance with the qualitative research descriptive analysis technique. This research was carried out in Ersoy Middle School 7/A and 7/C classes in Kepez district of Antalya province in the 2018-2019 academic year. The study was conducted with two groups as Experiment and Control (62 students), while the experimental group students (7/A class) received training with the Argumentation-based learning method, the control group ( $7 / \mathrm{C}$ class) was trained as prescribed by the curriculum. 15 girls and 16 boys in the control group and 16 girls and 15 boys in the experimental group were studied. In the experimental and control groups, care was taken to ensure that the teaching time and the ambient conditions of the classes were equal. Experimental and control groups were assigned randomly.

Statistical operations were performed on the data collected through measurement tools. SPSS 23 package program was used for statistical operations. The Mann-Whitney U test, which is used to measure whether the scores obtained from two unrelated samples differ or not, was used in this study to determine whether there was a significant difference between the pre-test and post-test scores of the experimental and comparison groups. The Wilcoxon test was used to determine how different the pre-test and post-test scores differed for each group. The Wilcoxon test is a test used to examine the significance of the difference between the scores of two related sets of measurements (Büyüköztürk, 2012, p.162). The values obtained as a result of the research were calculated at .05 significance level.

\section{Results, discussion and conclusion:}

When the effect of argumentation-based learning on student achievement in the courses of middle school seventh grade students was examined, it was found that there was no significant difference between the pretest scores of the students in the experimental group and the students in the control group. When the effect of argumentation-based learning on student achievement in the lessons of middle school seventh grade students was examined, it was determined that there was a significant difference in favor of the experimental group between the posttest scores of the students in the experimental group and the students in the control group. When the effect of argumentation-based learning on student achievement in the lessons of middle school seventh-grade students was examined, it was found that the post-test success scores of the students in the experimental group increased significantly compared to their pre-test success scores. This situation can be explained by the way that argumentation-based learning increases student achievement in social studies lesson 
teaching. When the effect of argumentation-based learning on student achievement in the lessons of middle school seventh-grade students was examined, it was found that the post-test success scores of the students in the control group increased significantly compared to their pre-test success scores. It was concluded that there was no significant relationship between the attitude scale pre-application scores of the students in the experimental group and the attitude scale pre-application scores of the students in the control group. It was determined that there was a significant relationship in favor of the experimental group between the postapplication attitude scale scores of the students in the experimental group and the post-application attitude scale scores of the students in the control group. It was determined that there was a significant relationship between the attitude scores of the students in the experimental group before the experimental procedure and their attitude scores after the experimental procedure after the experimental procedure. It was determined that there is a significant relationship between the attitude scores before the application and the post-application attitude scores of the students in the control group in favor of the post-procedure application.

There are studies stating that Argumentation-Based Instruction increases student success not only in the subjects of the 'Science, Technology and Society' unit but also in other subjects related to social information. The results obtained from these studies coincide with the results obtained in this study. Examples from these studies on social studies course subjects can be given. Cevger (2018) stated that a significant difference emerged in favor of the experimental group in which the argumentation-based learning method was applied in the study, in which he examined the effect of the use of the "Argumentation-Based Learning Method on the academic achievement and scientific discussion levels of the students in the social studies course. Torun (2015) examined the relationship between argumentation-based teaching and decision-making skills in social studies course and found that student argument levels showed a positive increase from the first activity to the last activity and that students' success increased.

\section{Giriş}

Argümantasyon; fikirlerin diyalog süreciyle araştırıldığı, daima öğrencilerin soru sordukları, iddiaları delillerle destekledikleri tartışma ve açıklamaları yapılandırdıkları, ayrıca birbirlerinin fikirlerini eleştirip değerlendirdikleri sosyal bir aktivitedir (Chin ve Osborne, 2010, s.883). Willard' a göre argümantaston, karş1 fikirlere sahip iki veya daha fazla kişinin argümanlarını geliştirdiği, savunduğu ve karşılaştırdığı sosyal bir faaliyettir (Akt., Felton ve Kuhn, 2001, s.135). Sampson ve Clark (2008) argümantasyonu bireylerin argüman oluştururken kullandıkları yapıların meydana getirdiği karmaşık süreçlerin bütünü olarak tanımlamaktadırlar. Argümantasyonda bir kişi iddiayı desteklemek için argüman oluşturabilir. İki veya daha fazla kişi karşıt iddialarını tartıştıkları diyalog sürecinde, argüman üründen ziyade tartışma süreci olarak adlandırılabilir (Kuhn ve Undell, 2007, s.91). Torun ve Şahin'e (2016) göre ise argümantasyon bir öğretme yöntemi olasına rağmen, aynı zamanda insanların gündelik hayatta bilinçli veya bilinçsiz olarak dâhil olduğu bir süreç olarak ifade edilir (s.234). Argümantasyonu ileri sürülen farklı görüşlerin bilimsel geçerliliği olan dayanaklara göre makul bulunduğu veya kabul edilmediği tartışma süreci olarak ifade edebiliriz (Cevger, 2018, s.22).

Literatürde argümantasyon birçok farklı boyutta ele alınmıştır. Bunlardan bazıları şunlardır: Argümanatsyon; önemli bir günlük yaşam becerisidir; çünkü insanlar, eldeki kanıta dayanarak ne yapılacağına karar vermek zorunda oldukları durumlarla sıkça karşı karşıya kalır. Argümantasyon, okullarda bilimsel sorgulamanın özünü oluşturur (Üstünel ve Tokel, 2017).

Argümantasyon yönteminin öğrenci başarısı ve tutumları üzerindeki etkisinin araştırıldığı birçok araştırma yapılmıştır (Ardaç, Erduran ve Yakmacı Güzel, 2009; Şekerci, 2013; Öztürk, 2013; aydeniz ve Özdilek, 2015; Balc1, 2015; Ulu ve Bayram, 2015; Torun, 2015; Çiftçi, 2016; Tuncel, 2016; Aktaş, 2017; Harman ve Çelikler, 2017). Ortaokul öğrencilerinin çeşitli bilim alanlarının farklı ünite ve konuları ile ilgili argümantasyon düzeylerinin belirlenmesi üzerine de bazı çalışmalar yürütülmüştür (Çetin, Kutluca ve Kaya, 2014; Özcan, 2015; Özcan, Aktamış ve Hiğde, 2018; Uluçınar Sağır, Soylu ve Bolat, 2021). 
Sosyal Bilgiler Dersi Öğretim Programı'nın vizyonu 21. yüzyılın çağdaş, Atatürk İlkelerini ve İnkılâplarını benimsemiş, Türk tarihini ve kültürünü kavramış, temel demokratik değerlerle donanmış, insan haklarına saygılı, yaşadığı çevreye duyarlı, bilgiyi deneyimlerine göre yorumlayabilen, eleştirel düşünebilen, yaratıcı, sosyal katılım becerileri gelişmiş, sosyal yaşamda etkin, üretken, haklarını ve sorumluluklarını bilen, Türkiye Cumhuriyeti vatandaşları yetiştirmektir (MEB, 2005). Hedeflenen birey tipinin yetiştirilebilmesi için eğitim programlarında öğrencilerin bu yönlerini geliştirecek tartışma ortamlarının oluşturulabileceği uygun konuların yer alması gerekmektedir. Toplumsal konular öğrencilere bu ortamı sağlayabilecek uygun örnekler barındırmaktadır. Toplumsal sorunları içeren konuların sınıflarda tartışılması ve bu sorunlarla ilgili karar verme sürecinin öğrenme eylemi ile bütünleştirilmesi önemli bir eğitsel amaç haline gelmelidir. Bu amaçla toplumsal sorunların eğitim ortamlarına taşınması gerektiğini savunan Sadler ve Fowler (2006) okullarda verilen eğitimin bilim ve toplum arasındaki dinamik ilişkiyi yansıtması gerektiğini belirtmiştir. Dolayısıyla argümana dayalı öğretimin amacı, öğrenenleri aktif olarak sorgulamaya ve düşünmeye yönlendirmektedir (Öztürk, 2013). Bu sebeple argümana dayalı sorgulama yöntemi öğretim sürecinde etkin olarak uygulanmalidır.

Argümantasyon; ortaya atılan gerçekler ile iddiaların kanıtlanması ya da çürütülmesine dayalı bir bilimsel tartışmadır. Argümantasyon yöntemi öğrencilerin eleştirel düşünmelerini sağlamak ile birlikte kavramsal öğrenmelerinde ve akademik başarılarının arttırılmasında etkili bir yöntem olarak karşımıza çıkmaktadır. Bu yüzden yapılan çalışmanın argümantasyon yönteminin sosyal bilgiler eğitiminde öğrenci başarısını arttırmada ve bir topluluk önünde düşüncelerini ortaya koyma becerilerini geliştirmede önemli olabileceği düşünülmektedir. Bu araştırmanın ortaokul düzeyinde Sosyal Bilgiler Dersi'nin Bilim Teknoloji ve Toplum Ünitesi'nde Argümantasyon Tabanlı Öğrenme etkinliklerine yer veren ilk araştırma olması bakımından Sosyal Bilgiler öğretmenlerine kılavuzluk edebileceği ve gelecekteki araştırmacılara yol göstereceği düşünülmektedir.

Ayrıca argümantasyon yöntemine ilişkin yapılan önceki araştırmalara bakıldığında fen bilgisi dersiyle ilgili oldukça çok araştırmanın yapıldığı dikkatleri çekmektedir. Konu ile ilgili Sosyal Bilgiler Eğitimi alanına bakıldığında ise argümantasyon yöntemi kullanımı üzerine yapılan çok az sayıda çalışma vardır. Bu araştırma Sosyal Bilgiler Eğitimi alanındaki bu eksikliği giderme gibi amaçlar açısından önem taşımaktadır.

\subsection{Problem Cümlesi}

Sosyal bilgiler eğitiminde bilim teknoloji ve toplum ünitesinin öğrenilmesinde Argümantasyon Tabanlı Öğrenme sürecinin etkisi nasıldır? Bu problem doğrultusunda cevap aranan alt problemler aşağıda verilmiştir.

\subsection{Alt Problemler}

1. Ortaokul 7. Sınıf öğrencilerinin öntest başarı puanları gruba (Deney-Kontrol) göre farklılaşmakta midir?

2. Ortaokul 7. Sınıf öğrencilerinin sontest başarı puanları gruba (Deney-Kontrol) göre farklılaşmakta midir?

3. Deney grubunun öntest başarı puanları ile sontest başarı puanları arasında anlamlı bir fark var mıdır?

4. Kontrol grubunun öntest başarı puanları ile sontest başarı puanları arasında anlamlı bir fark var midir?

5. Ortaokul 7. sınıf öğrencilerinin deneysel işlem öncesi tutum puanları gruba (Deney-Kontrol) göre farklılaşmakta mıdır?

6. Ortaokul 7. sınıf öğrencilerinin deneysel işlem sonrası tutum puanları gruba (Deney-Kontrol) göre farklılaşmakta mıdır?

7. Deney grubunun deneysel işlem öncesi tutum puanları ile deneysel işlem sonrası tutum puanları arasinda anlamlı bir fark var midir?

8. Kontrol grubunun deneysel işlem öncesi tutum puanları ile deneysel işlem sonrası tutum puanları arasında anlamlı bir fark var midir? 
9. Ortaokul 7. sınıf öğrencilerinin derslerinde uygulanan argümantasyon temelli öğretime yönelik görüşleri nelerdir?

\section{Yöntem}

$\mathrm{Bu}$ araştırma nicel araştırma yöntemine uygun olarak tasarlanmıştır. Araştırmada ön test-son test karşılaştırma gruplu yarı deneysel desen kullanılmıştır. Ön test-son test karşılaştırma gruplu desen, katılımcıların deneysel araştırmanın öncesinde ve sonrasında, bağımlı değişken ile ilgili ölçüme tabi tutulmasıdır (Karasar, 1999, s.86). Araştırmanın son alt probleminin veri toplama ve analizi ise nitel araştırma betimsel analiz tekniğine uygun bir şekilde gerçekleştirilmiştir.

\section{Örneklem}

Bu araştırma 2018-2019 eğitim öğretim yılında Antalya ili Kepez İlçesinde bulunan Ersoy Ortaokulu 7/A ve 7/C sınıflarında gerçekleştirilmiştir. Deney ve Kontrol olmak üzere iki grupla çalışılmış (62 öğrenci), deney grubu öğrencileri (7/A sınıfi) Argümantasyon tabanlı öğrenme yöntemi ile eğitim alırken, kontrol grubuna (7/C sınıfi) ise müfredatın öngördüğü şekilde eğitim verilmiştir. Kontrol grubunda $15 \mathrm{k1z}, 16$ erkek ve deney grubunda ise $16 \mathrm{kız}, 15$ erkek öğrenci ile çalışılmıştır. Deney ve kontrol gruplarında ders işleme süresi ve sınıfların ortam şartlarının eşit olmasına dikkat edilmiştir. Deney ve kontrol grupları seçkisiz olarak tayin edilmiştir.

\section{Veri toplama yöntemleri ve araçları}

Araştırmada kullanılan verileri toplamak için sosyal bilgiler dersine yönelik tutum ölçeği, argümantasyon yöntemi görüşme formu ve argümantasyon tabanlı öğretime uygun etkinlikler tasarlanmıştır. Araştırmaya katılan deney ve kontrol grubu öğrencilerinin sosyal bilgiler dersine yönelik tutumlarını ölçmek için Özkal (2000) tarafindan geliştirilen "Sosyal Bilgiler Tutum Ölçeğii” kullanılmıştır. Özkal'ın geliştirdiği bu ölçek 3'lü Likert tipinde katılıyorum, kararsızım ve katılmıyorum seçeneklerinden oluşmaktadır. Ölçekte 31 madde bulunmaktadır. İzmir ilinde üç farklı okulda 4. ve 5. sınıf toplam 214 öğrenciye uygulanarak ölçeğin yapı geçerlilik güvenirlik çalışması yapılmıştır. Sonuç olarak analiz edilen ölçeğin Cronbach Alpha Katsayısı 0.91 olarak bulunmuştur. Yarı güvenirliği ise analiz sonucunda Spearman- Brown 0.88 olarak hesaplanmıştır. Ölçekteki 31 madde duygu, çalışmayı sürdürme ve isteklilik, katılma ve hoşlanma adı altında dört faktörden oluşmaktadır. 31 madddenin kategorize edilmiş haline göre Cronbach Alpha güvenirlik katsayıları duygu katsayıları 0.76, çalışmayı sürdürme ve isteklilik için 0.79 , katılma için 0.73 ve hoşlanma için 0.83 olarak hesaplanmıştır. Elde edilen verilere göre tutum ölçeğinin geçerli ve güvenilir olduğu sonucuna ulaş1lmıştır. Araştırmacı tarafından geliştirilen görüşme formu literatür taraması, alternatif soruların belirlenmesi, soru havuzunun oluşturulması, 3 alan uzmanının ve 1 ölçme ve değerlendirme alan uzmanının görüşüne başvurulması, soruların revize edilmesi ve görüşme formuna son halinin verilmesi ile oluşturulmuştur.

\section{Verilerin analizi}

Ölçme araçları yoluyla toplanan veriler üzerinde istatistiksel işlemler gerçekleştirilmiştir. İstatistiksel işlemler için SPSS 23 paket programından yararlanılmıştır. İki ilişkisiz örneklemden elde edilen puanların farklılaşıp farklılaşmadığını ölçmek için kullanılan Mann-Whitney $U$ testi bu çalışmada, deney ve karşılaştırma gruplarının ön test ve son test puanları arasında anlamlı bir fark olup olmadığını belirlemek için kullanılmıştır. Grupların her biri için, ön test ve son test puanlarının ne kadar farklılaştığını belirleyebilmek için ise, Wilcoxon testi kullanılmıştır. Wilcoxon testi, ilişkili iki ölçüm setine ait puanlar arasında farkın anlamlılığını incelemek için kullanılan bir testtir (Büyüköztürk, 2012, s.162). Araştırma sonucunda elde edilen değerler .05 anlamlılık düzeyinde hesaplanmıştır. 


\section{Bulgular}

$\mathrm{Bu}$ bölümde araştırma sürecinde elde edilen verilerin analiz edilmesi sonucu ulaşılan bulgulara ve bu bulgulara ilişkin yorumlara yer verilmiştir.

Deney ve kontrol grubuna ait veriler analiz edilmeden önce verilerin normallik değerleri incelenmiştir. Deney ve kontrol grubunun ön test ve son test puanlarının normallik testine ait verileri şu şekildedir.

Tablo 1. Deney ve kontrol gruplarının başarı testine ilişkin normallik değerleri

\begin{tabular}{lllll}
\hline Testler & Gruplar & Kolmogorov-Smirnov & Skewness & Kurtosis \\
\hline \multirow{2}{*}{ Ön test } & Deney &, 855 &, 096 &,- 056 \\
& Kontrol &, 004 & $-1,253$ & 1,782 \\
\hline \multirow{2}{*}{ Son test } & Deney &, 000 &,- 708 &,- 808 \\
& Kontrol &, 000 & $-2,051$ & 5,856 \\
\hline
\end{tabular}

Tablo 1 incelendiğinde çarpıklık ve basıklık katsayılarının $+1,5$ ile $-1,5$ aralığında olmaması verilerin normallik değerlerini sağlamadığını göstermektedir (Tabachnick ve Fidell, 2015). Ayrıca KolmogorovSmirnov değerlerinin 0,05 düzeyinde anlamlı olduğu, yani verilerin normal dağılmadığı görülmektedir $(\mathrm{p}<0.05)$. Bu durumda istatistik tekniklerde non-parametrik testler tercih edilmiştir.

\section{Birinci Alt Probleme İlişkin Bulgular}

Deney ve kontrol gruplarının ön test puan ortalamaları arasında anlamlı bir ilişkinin olup olmadığını incelemek amacıyla Mann Whitney U-Testi analizi yapılmıştır. İki grubun ön test puanları arasında anlamlı bir ilişkinin olmaması çalışmanın sürdürülebilmesi açısından önem taşımaktadır. Bu doğrultuda yapılan analize ilişkin bilgiler şu şekildedir.

Tablo 2. Ortaokul 7. Sınıf Öğrencilerinin Başarı Testi Öntest Puanlarının Gruba Göre U-Testi Sonucu

\begin{tabular}{llllll}
\hline Grup & N & Sira Ortalaması & Sira Toplamı & U & p \\
\hline Deney & 31 & 29,32 & 909,00 & 413,00 &, 338 \\
Kontrol & 31 & 33,68 & 1044,00 & & \\
\hline
\end{tabular}

Uygulama öncesindeki başarı testi puanlarının U-testi sonuçları Tablo 2'de verilmiştir. Buna göre deneysel çalışma öncesinde, Argümantasyon yöntemi programına katılan öğrencilerle böyle bir programa katılmayan öğrencilerin "başarı testi” puanları arasında anlamlı bir fark olmadığ 1 tespit edilmiştir. U=413,00, $\mathrm{p}>0.05$. Sıra ortalamaları dikkate alındığında, Argümantasyon yöntemi programına katılan öğrencilerin, programa katılmayan öğrencilere göre "başarı testi” puanlarının daha düşük olduğu anlaşılmaktadır. Bu bulgu, deneysel çalışma öncesinde grupların "başarı testi” puanlarının birbirine yakın olduğunu gösterir.

\section{2. İkinci Alt Probleme iliş̧kin Bulgular}

Tablo 3. Ortaokul 7. Sınıf Öğrencilerinin Başarı Testi Sontest Puanlarının Gruba Göre U-Testi Sonucu

\begin{tabular}{llllll}
\hline Grup & $\mathbf{N}$ & Sira Ortalaması & Sira Toplamı & $\mathbf{U}$ & $\mathbf{p}$ \\
\hline Deney & 31 & 41,15 & 1275,50 & & \\
Kontrol & 31 & 21,85 & 677,50 & &, 000 \\
\hline
\end{tabular}


Uygulama sonrasındaki başarı testi puanlarının U-testi sonuçları Tablo 3'de verilmiştir. Buna göre deneysel çalışma sonrasında, Argümantasyon yöntemi programına katılan öğrencilerle böyle bir programa katılmayan öğrencilerin "başarı testi" puanları arasında anlamlı bir fark olduğu tespit edilmiştir. U=181,500, $\mathrm{p}<0.05$. Sıra ortalamaları dikkate alındığında, Argümantasyon yöntemi programına katılan öğrencilerin, programa katılmayan öğrencilere göre "başarı testi” puanlarının daha yüksek olduğu anlaşılmaktadır. Bu bulgu, deneysel çalışma sonrasında grupların "başarı testi” puanlarının deney grubu lehine anlamlı düzeyde yüksek olduğunu göstemektedir.

\section{3. Üçüncü Alt Probleme ilişkin Bulgular}

Deney grubunda yer alan öğrencilerin ön test ve son test puanları arasında anlamlı bir ilişkinin olup olmadığını incelemek amacıyla Wilcoxon İşaretli Sıralar testi yapılmıştır. Yapılan analize ait bilgiler şu şekildedir.

Tablo 4. Deney Grubunun deney öncesi ve sonrası Başarı Testi Puanlarının Wilcoxon İşaretli Sıralar Testi Sonuçları

\begin{tabular}{llllll}
\hline Sontest-Öntest & $\mathbf{N}$ & Sıra Ortalaması & Sira Toplamı & $\mathbf{z}$ & $\mathbf{p}$ \\
\hline Öntest & 0 &, 00 &, 00 & & \\
Sontest & 31 & 16,00 & 496,00 & $-4,866$ &, 000 \\
Eșit & 0 & & & & \\
\hline
\end{tabular}

*Negatif sıralar temeline dayalı $* \mathbf{p}<0.05$

Tablo 4. incelendiğinde deney grubunun başarı testine ait ön test puan ortalamasının $(\bar{X}=, 50)$ son test puan ortalamasından $(\bar{X}=16,00)$ düşük olduğu görülmektedir. Yapılan analiz sonucunda deney grubunun ön test ve son test puan ortalamaları arasında son test puan ortalamaları lehine anlamlı bir ilişkinin olduğu, dolayısıyla Argümantasyon Yöntemi kullanımının öğrenci başarıları üzerinde olumlu etkisinin olduğu söylenebilmektedir.

\section{Dördüncü Alt Probleme ilişkin Bulgular}

Kontrol grubunda yer alan öğrencilerin ön test ve son test puanları arasında anlamlı bir ilişkinin olup olmadığını incelemek amacıyla bağımlı örneklem grupları içi Wilcoxon İşaretli Sıralar testi analizi yapılmıştır. Yapılan analize ait bilgiler şu şekildedir.

Tablo 5. Kontrol grubunun uygulama öncesi ve sonrası Başarı Testi Puanlarının Wilcoxon İşaretli Sıralar Testi Sonuçları

\begin{tabular}{llllll}
\hline Sontest-Öntest & $\mathbf{N}$ & Sıra Ortalaması & Sira Toplamı & $\mathbf{z}$ & $\mathbf{p}$ \\
\hline Öntest & 1 & 13,50 & 13.50 & $-6,759$ &, 000 \\
Sontest & 61 & 31,80 & 1939.50 & & \\
Eşit & 0 & & & & \\
\hline
\end{tabular}

*Negatif sıralar temeline dayalı

$* \mathbf{p}<0.05$

Tablo 5. incelendiğinde kontrol grubunun başarı testine ait ön test puan ortalamasının $(\bar{X}=13,50)$ son test puan ortalamasından $(\bar{X}=31,80)$ düşük olduğu görülmektedir. Yapılan analiz sonucunda kontrol 
grubunun ön test ve son test puan ortalamaları arasında son test puan ortalamaları lehine anlamlı bir ilişkinin olduğu anlaşılmaktadır.

\section{Beşinci Alt Probleme i̇lişkin Bulgular}

Deney ve kontrol gruplarının tutum ölçeği ön uygulama puanları arasında anlamlı bir ilişkinin olup olmadığını incelemek amacıyla Mann Whitney U-Testi analizi yapılmıştır. Yapılan analize ait bilgiler şu şekildedir.

Tablo 6. Ortaokul 7. Sınıf Öğrencilerinin Tutum Ölçeği Ön-Uygulama Puanlarının Gruba Göre U-Testi Sonucu

\begin{tabular}{llllll}
\hline Grup & N & Sira Ortalaması & Sira Toplamı & U & p \\
\hline Deney & 31 & 31,18 & 966,50 & \multirow{2}{*}{470,500} &, 888 \\
Kontrol & 31 & 31,82 & 986,50 & & \\
\hline
\end{tabular}

Uygulama öncesindeki tutum ölçeği puanlarının U-testi sonuçları Tablo 6'da verilmiştir. Buna göre deneysel çalışma öncesinde, Argümantasyon yöntemi programına katılan öğrencilerle böyle bir programa katılmayan öğrencilerin "tutum ölçeği" puanları arasında anlamlı bir fark olmadığı tespit edilmiştir. $\mathrm{U}=470,500, \mathrm{p}>0.05$. Sıra ortalamaları dikkate alındığında, Argümantasyon yöntemi programına katılan öğrencilerin, programa katılmayan öğrencilere göre "tutum ölçeği" puanlarının daha düşük olduğu anlaşılmaktadır. Bu bulgu, deneysel çalışma öncesinde grupların "tutum ölçeği”" puanlarının birbirine yakın olduğunu gösterir.

\section{Altıncı Alt Probleme illişkin Bulgular}

Deney ve kontrol gruplarının tutum ölçeği son-uygulama puanları arasında anlamlı bir ilişkinin olup olmadığını incelemek amacıyla Mann Whitney U-Testi analizi yapılmıştır. Yapılan analize ait bilgiler şu şekildedir.

Tablo 7. Ortaokul 7. Sınıf Öğrencilerinin Tutum Ölçeği Son-Uygulama Puanlarının Gruba Göre U-Testi Sonucu

\begin{tabular}{|c|c|c|c|c|c|}
\hline Grup & $\overline{\mathbf{N}}$ & Sira Ortalaması & Sıra Toplamı & $\overline{\mathbf{U}}$ & \\
\hline Deney & 31 & 36,03 & 1117,00 & \multirow{2}{*}{340,000} & \multirow{2}{*}{, 047} \\
\hline Kontrol & 31 & 26,97 & 836,00 & & \\
\hline
\end{tabular}

Uygulama sonrasındaki tutum ölçeği puanlarının U-testi sonuçları Tablo 7'de verilmiştir. Buna göre deneysel çalışma sonrasında, Argümantasyon yöntemi programına katılan öğrencilerle böyle bir programa katılmayan öğrencilerin "tutum ölçeği”" puanları arasında anlamlı bir fark olduğu tespit edilmiştir $U=340,000$, $\mathrm{p}<0.05$. Sıra ortalamaları dikkate alındığında, Argümantasyon yöntemi programına katılan öğrencilerin, programa katılmayan ögrencilere göre "tutum ölçeği” puanlarının daha yüksek olduğu anlaşılmaktadır. Bu bulgu, deneysel çalışma sonrasında grupların "tutum ölçeği” puanlarının deney grubu lehine anlamlı düzeyde yüksek olduğunu göstermektedir.

\section{Yedinci Alt Probleme ilişkin Bulgular}

Deney grubunda yer alan öğrencilerin tutum ölçeği ön-uygulama ve son-uygulama puanları arasında anlamlı bir ilişkinin olup olmadığını incelemek amacıyla Wilcoxon İşaretli Sıralar testi yapılmıştır. Yapılan analize ait bilgiler şu şekildedir. 
Tablo 8. Deney Grubunun deney öncesi ve sonrası tutum ölçeği Puanlarının Wilcoxon İşaretli Sıralar Testi Sonuçları

\begin{tabular}{llcccc}
\hline Sontest-Öntest & $\mathbf{N}$ & Sıra Ortalaması & Sira Toplamı & $\mathbf{z}$ & $\mathbf{p}$ \\
\hline Öntest & 4 & 10,50 & 42,00 &, 000 \\
Sontest & 26 & 16,27 & 423,00 & $-3,920$ & \\
Eşit & 1 & & & \\
\hline
\end{tabular}

*Negatif sıralar temeline dayalı

*p $<0.05$

Tablo 8. incelendiğinde deney grubunun tutum ölçeğine ait ön-uygulama puan ortalamasının $(\bar{X}=10,50)$ son-uygulama puan ortalamasından $(\bar{X}=16,27)$ düşük olduğu görülmektedir. Yapılan analiz sonucunda deney grubunun tutum ölçeği ön-uygulama ve son-uygulama puan ortalamaları arasında son-uygulama puan ortalamaları lehine anlamlı bir ilişkinin olduğu, dolayısıyla Argümantasyon Yöntemi kullanımının öğrencilerin sosyal bilgiler dersine yönelik tutumları üzerinde olumlu etkisinin olduğu söylenebilmektedir.

\section{Sekizinci Alt Probleme ílişkin Bulgular}

Kontrol grubunda yer alan öğrencilerin tutum ölçeği ön-uygulama ve son-uygulama puanları arasında anlamlı bir ilişkinin olup olmadığını incelemek amacıyla Wilcoxon İşaretli Sıralar testi yapılmıştır. Yapılan analize ait bilgiler şu şekildedir.

Tablo 9. Kontrol Grubunun deney öncesi ve sonrası tutum ölçeği Puanlarının Wilcoxon İşaretli Sıralar Testi Sonuçları

\begin{tabular}{llllll}
\hline Sontest-Öntest & $\mathbf{N}$ & Sira Ortalaması & Sıra Toplamı & $\mathbf{z}$ & $\mathbf{p}$ \\
\hline Öntest & 5 & 7,50 & 37,50 & $-2,357$ &, 018 \\
Sontest & 14 & 10,89 & 152,50 & & \\
Eșit & 12 & & & & \\
\hline
\end{tabular}

*Negatif sıralar temeline dayalı

$* \mathbf{p}<0.05$

Tablo 9. incelendiğinde kontrol grubunun tutum ölçeğine ait ön-uygulama puan ortalamasının $(\bar{X}=7,50)$ son-uygulama puan ortalamasından $(\bar{X}=10,89)$ düşük olduğu görülmektedir. Yapılan analiz sonucunda kontrol grubunun tutum ölçeği ön-uygulama ve son-uygulama puan ortalamaları arasında son-uygulama puan ortalamaları lehine anlamlı bir ilişkinin olduğu, dolayısıyla müfredata uygun ders işlemenin öğrencilerin sosyal bilgiler dersine yönelik tutumları üzerinde olumlu etkisinin olduğu söylenebilmektedir.

\section{Dokuzuncu Alt Probleme ilişsin Bulgular}

Yedinci sınıf öğrencilerinin görüşme formunda yer alan soruda; “Argümantasyon yönteminin sosyal bilgilerin diğer ünitelerinde de uygulanmasını ister misiniz?', verdikleri cevapların analizi soncucunda öğrencilerden 30'u evet, 2'si hayır cevabını verdikleri tespit edilmiştir. Oluşan kategoriler ve doğrudan katılımcı görüşleri şöyledir 


\section{Evet (K16,K19,K21,K22)}

K16: Diğer ünitelerde uygulansin.

K19: Evet, çünkü severim.

K21: Evet, uygulansin.

K22: Evet, çünkü iyi bir şekilde anlatıyor. Evet diğer ünitelerde isterim.

\section{Kalıcılı̆̆ı artırma $(\mathrm{K} 1, \mathrm{~K} 5, \mathrm{~K} 6, \mathrm{~K} 7, \mathrm{~K} 18, \mathrm{~K} 24)$}

K1: Akılda kalıcı oluyor. Unuttuğum zaman kodlanan kelimelerden aklımda kalıyor.

K5: Akılda kalıc1.

K6: Evet, çünkü aklıma daha iyi oturuyor ve daha kalıcı oluyor.

K18: Evet, çünkü konuyla ilgili bütün bilgiler aklımda kalıyor.

K24: Evet, çünkü aklımda daha kalıcı oluyor.

\section{Daha rahat anlama $(\mathrm{K} 2, \mathrm{~K} 10, \mathrm{K11}, \mathrm{K14})$}

K2: Daha rahat anliyoruz.

K10: Evet, çünkü daha iyi anlamamızı yardımcı oluyor.

K11: Evet, çünkü daha iyi öğrenmemi sağlıyor.

K14: Evet, çünkü iyi bir şekilde anlatıldı. Diğer ünitelerde olursa konular çok daha iyi öğreniriz.

Güzel ve eğlenceli bir yöntem (K3,K4,K5,K7,K8,K9,K12,K15,K17,K20,K23,K29)

K3: Çok güzel ve iyi bir yöntem.

K4: Evet, çünkü eğlenceli ve güzel diğer ünitelerde isterim.

K5: Eğlenceli.

K7: Evet, diğer ünitelerde uygulanmasını isterim. Eğlenceli ve akılda kalıcı oluyor.

K8: Evet, çünkü daha eğlenceli.

K9: Evet, çünkü seviyorum.

K12: Evet, çünkü çok seviyorum.

K15: Evet, çünkü daha iyi anlatıyor. Bunu diğer ünitelerde görmek isterim.

K17: Evet, isterim çünkü dünyanın en güzel yöntemi.

K20: Evet, çünkü çok iyi ve bizi eğlendiriyor.

K23: Evet, çünkü bu yöntemle daha eğlenceli ve zevkli geçer.

K29: Evet, çünkü iyi bir yöntem ve isterim. Eğlenceli ve bana sosyali sevdirdi.

Hayır (K13,K25)

K13: Hayır, çünkü daha iyi anlamama sebep oldu.

K25: Sosyal bilgiler öğretmenimizin ders anlatım şeklinden memnunum. 


\section{Sonuç, Tartışma ve Öneriler}

Bu bölümde; araştırmada elde verilerin çözümlenmesiyle ortaya çıkan bulgular ve bu bulguların ilgili literatürün sonuçlarıyla karşılaştırılması ve ulaşılan sonuçlar doğrultusunda verilen öneriler yer almaktadır.

Sosyal bilgiler dersinde argümantasyon temelli öğrenme yöntemi kullanılarak elde edilen veriler nicel araştırma yöntemleri yoluyla derlenmiş ve SPSS üzerinde çözümlenmiştir. Verilerin toplanmasında araştırmacı tarafindan geliştirilen başarı testi ve Özkal (2000) tarafindan geliştirilen tutum ölçeği kullanılmıştır. Verilerin analizi ile ulaşılan sonuçlar ve bu sonuçlara ilişkin tartışmalar şöyledir:

Ortaokul yedinci sınıf öğrencilerinin derslerinde argümantasyon temelli öğrenmenin öğrenci başarısı üzerine etkisi incelendiğinde, deney grubunda yer alan öğrenciler ile kontrol grubunda yer alan öğrencilerin başarı testine ait öntest puanları arasında anlamlı bir farkın olmadığı tespit edilmiştir.

Ortaokul yedinci sınıf öğrencilerinin derslerinde argümantasyon temelli öğrenmenin öğrenci başarısı üzerine etkisi incelendiğinde, deney grubunda yer alan öğrenciler ile kontrol grubunda yer alan öğrencilerin başarı testine ait sontest puanları arasında deney grubu lehine anlamlı bir farkın olduğu belirlenmiştir.

Ortaokul yedinci sınıf öğrencilerinin derslerinde argümantasyon temelli öğrenmenin öğrenci başarısı üzerine etkisi incelendiğinde, deney grubunda yer alan öğrencilerin son-test başarı puanlarının ön-test başarı puanlarına göre anlamlı bir şekilde arttığı tespit edilmiştir. $\mathrm{Bu}$ durum sosyal bilgiler dersi öğretiminde argümantasyon temelli öğrenmenin öğrenci başarısını arttırdığı şeklinde de açıklanabilir. Ortaokul yedinci sınıf öğrencilerinin derslerinde argümantasyon temelli öğrenmenin öğrenci başarısı üzerine etkisi incelendiğinde, kontrol grubunda yer alan öğrencilerin son-test başarı puanlarının ön-test başarı puanlarına göre anlamlı bir şekilde arttı̆̆ tespit edilmiştir.

Deney grubunda yer alan öğrencilerin tutum ölçeği ön-uygulama puanları ile kontrol grubunda yer alan öğrencilerin tutum ölçeği ön-uygulama puanları arasında anlamlı bir ilişkinin olmadığı sonucuna ulaşılmıştır. Deney grubunda yer alan öğrencilerin uygulama sonrası tutum ölçeği puanları ile kontrol grubunda yer alan öğrencilerin uygulama sonrası tutum ölçeği puanları arasında deney grubu lehine anlamlı bir ilişkinin olduğu tespit edilmiştir.

Deney grubunda yer alan öğrencilerin deneysel işlem öncesi tutum puanları ile deneysel işlem sonrası tutum puanları arasında deneysel işlem sonrası lehine anlamlı bir ilişkinin ortaya çıktığı belirlenmiştir. Kontrol grubunda yer alan ögrencilerin uygulama öncesi tutum puanları ile uygulama sonrası tutum puanları arasında işlem sonrası uygulama lehine anlamlı bir ilişkinin olduğu tespit edilmiştir.

Argümantasyona Dayalı Öğretimin sadece 'Bilim Teknoloji ve Toplum' ünitesinin konularında değil sosyalbBilgilere ait diğer konularda da öğrenci başarısını arttırdığını anlamlı öğrenmeler oluşturduğunu belirten çalışmalar bulunmaktadır. Bu çalışmalardan ulaşılan sonuçlar bu çalışmada elde edilen sonuçlarla örtüşmektedir. Sosyal bilgiler dersi konularıyla ilgili yapılan bu çalışmalardan örnekler verilebilir. Cevger (2018) sosyal bilgiler dersinde ‘Argümantasyon Tabanlı Öğrenme Yöntemi’nin kullanılmasının öğrencilerin akademik başarılarına, bilimsel tartışma düzeylerine etkisini incelediği araştırmada başarı açısından argümantasyon tabanlı öğrenme yöntemi uygulanan deney grubu lehine anlamlı bir farklılık ortaya çıktığını belirtmiştir. Torun (2015) sosyal bilgiler dersinde argümantasyon temelli öğretim ve karar verme becerisi arasındaki ilişkiyi incelediği araştırmada öğrenci argüman düzeyleri ilk etkinlikten son etkinliğe doğru olumlu bir artış göstermiş ve öğrencilerin başarılarının arttığını belirlemiştir. Argümantasyon tabanlı öğrenme yöntemi ile ilgili literatür incelendiğinde konu ile ilgili fen bilimleri alanında da birçok araştırmaya ulaşmaktayız. Fen bilimlerinde argümantasyon tabanlı öğretimin uygulandığı araştırmalarda da argümantasyon tabanlı öğretimin öğrenci başarısını arttırdı̆̆ını belirten çalışmalar bulunmaktadır. Bu çalışmalara örnek; Acar (2008)'ın argümantasyon destekli fen öğretiminin 6. sınıf öğrencilerinin kavramsal anlamalarına, bilimsel düşünme becerilerine ve bilimin doğası anlayışlarına olan etkisini incelemiş̧lerdir. Çalışmanın sonucunda uygulamanın yapıldığı deney grubu öğrencilerinin düşünme becerilerinin geliştiği ve bilimin doğası anlayışlarının olumlu 
bir artış gösterdiğini belirtmiştir. Polat (2014) Atomun yapısı konusunda argümantasyon yönteminin ilköğretim 7. sınıf öğrencilerinin başarısı üzerine etkisini incelediği araştırmanın sonucunda, sontest sonuçlarında kontrol grubu ve deney grubu arasında deney grubunun lehine olumlu yönde bir değişme meydana geldiğini belirtmiştir. Okumuş (2012) maddenin halleri ve 1s1 ünitesinin bilimsel tartışma (argümantasyon) modeli ile öğretiminin öğrenci başarısına ve anlama düzeylerine etkisini incelemiştir. Araştırmada 8. sınıf öğrencilerine uyguladığı öğretim yöntemi sonucunda deney grubu ile kontrol grubunda bulunan öğrenciler arasında hem başarı açısından hem de kavramları anlama düzeyleri açısından olumlu yönde bir değişikliğin olduğunu ve öğrencilerin tartışma becerilerini de geliştirdiğini ifade etmiştir. Aldağ (2006) Toulmin Tartışma Modeli'ni değerlendirdiği çalışmada argümantasyon tabanlı öğretimin öğrencilerin tartışma becerilerini geliştirdiğini iddia etmiştir. Bütün bu yapılan araştırmaların sonuçlarına göre argümantasyon tabanlı olarak yapılan öğretimin öğrencilerin akademik başarısını arttırdığı ve sosyal bilgiler ve diğer derslere yönelik açıklama becerileri üzerinde olumlu etkide bulunduğu söylenebilir.

Araştırmanın bulgularından elde edilen sonuçlara dayalı olarak şu önerilerde bulunulabilir:

Bu çalışma sosyal bilgiler dersinin “'bilim teknoloji ve toplum” ünitesi kapsamında gerçekleştirilmiştir. Argümantasyona dayalı öğretimin sosyal bilgilerin diğer konularında da uygulanabilmesi ve etkililiğinin ölçülebilmesi için farklı okullarda ve sınıflarda uygulanması yararlı olabilir. Argümantasyon yöntemi farklı öğretim yöntemleri ile birlikte kullanılarak öğrencilerin ilgilerinin sürekliliği arttırılabilir. Öğrencilerin öz güven duygularını geliştirmek için diğer derslerde de argümantasyon odaklı öğretime yer verilmesi yararlı olabilir. Argümantasyona dayalı öğretim etkinlikleri yaygınlaştırılarak ve uygulamadaki olumlu etkisini test etmek için öğretmenler teşvik edilmelidir. Öğretmenlerin argümantasyona dayalı öğretim yapma konusundaki bilgi ve becerilerini arttırmak için hizmet içi kurslar düzenlenebilir. 


\section{Kaynakça}

Acar, Ö. (2008). Argumentation skills and conceptual knowledge of undergraduate students in a physics by inquiry class. (Unpublished doctoral dissertation). The Ohio State University, Columbus

Aktaş, T. (2017). Argümana dayali sorgulama ögretiminin yedinci sinif ögrencilerinin kuvvet ve enerji ünitesindeki akademik başarılarına ve argümantasyon seviyelerine etkisi. (Yayınlanmamış Yüksek Lisans Tezi). Marmara Üniversitesi, Eğitim Bilimleri Enstitüsü, İstanbul.

Aldağ, H. (2006). Toulmin tartışma modeli. Çukurova Üniversitesi Sosyal Bilimler Dergisi, 15(1), 13-34.

Aydeniz, M., \& Özdilek, Z. (2015). Assessing pre-service science teachers' understanding of scientific argumentation: what do they know about argumentation after four years of college science? Science Education International, 26 (2), 217-239.

Balcı, C. (2015). 8. sınıf ögrencilerine "hücre bölünmesi ve kalıtım” ünitesinin öğretilmesinde bilişsel argümantasyon temelli ögrenme sürecinin etkisi. (Yayınlanmamış Yüksek Lisans Tezi). Adnan Menderes Üniversitesi, Fen Bilimleri Enstitüsü, Aydın.

Büyüköztürk, Ş. (2012). Sosyal bilimler için veri analizi el kitabı. Ankara: Pegem Akademi.

Cevger, F. (2018). Sosyal bilgiler dersinde argümantasyon tabanli öğrenme yönteminin kullanilmasinin ögrencilerin akademik başarilarina, bilimsel düşünme becerilerine ve bilimsel tartişma düzeylerine etkisi. (Yayınlanmamış Doktora Tezi). Atatürk Üniverstesi Eğitim Bilimleri Enstitüsü, Erzurum.

Chin, C., \& Osborne, J. (2010). Supporting argumentation through students questions: Case studies in science classrooms. Journal of the Learning Sciences, 19(2), 230-284.

Çetin, P.S., Kutluca, A.Y. \& Kaya, E. (2014). Öğrencilerin argümantasyon kalitelerinin incelenmesi. Fen Bilimleri Ögretimi Dergisi, 2 (1) 56-66.

Çiftçi, A. (2016). 5., 6. ve 7. sinıflarda fen derslerinde argümantasyon kalitesinin incelenmesi (Yayımlanmamış Yüksek Lisans Tezi). Muş Alparslan Üniversitesi, Fen Bilimleri Enstitüsü, Muş.

Erduran, S., Ardaç, D. ve Yakmacı Güzel, B. (2006). Learning to teach argumentation: Case studies of preservice secondary science teachers. Eurasia Journal of Mathematics, Science and Technology Education, 2(2), 1-14.

Felton, M., \& Kuhn, D. (2001). The development of argumentive discourse skill. Discourse Processes, 32(23), 135- 153. https://doi.org/10.1207/S15326950DP3202\&3_03

Harman, G. \& Çelikler, D. (2017). Tuzların hidrolizi konusunun öğretiminde argümantasyon tabanlı bilim öğrenme yaklaşımının etkisi. Eğitim Bilimleri Dergisi, 46, 59-74.

Karasar, N. (1999). Bilimsel araştırma yöntemi (9. Baskı). Ankara: Nobel Yayın Dağıtım.

Kuhn, D. \& Undell, W. (2007). Coordinating own and other perspectives in argument. Thinking \& Reasoning, 13(2), 90-104.

MEB. (2005). İlköğretim sosyal bilgiler dersi 6 . 7. sinıflar öğretim program. http://ttkb.meb.gov.tr/ogretimprogramlari/icerik

Okumuş, S. (2012). Maddenin halleri ve isi ünitesinin bilimsel tartişma modeli ile ögretiminin ögrenci başarisina ve anlama düzeylerine etkisi. (Yayınlanmamış Yüksek Lisans Tezi). Karadeniz Teknik Üniverstesi, Eğitim Bilimleri Enstitüsü, Trabzon. 
Özcan, R. (2015). Fen bilimleri ögretmenlerinin argümantasyon sürecini sinıflarda uygulama düzeylerinin belirlenmesi. (Yayımlanmamış Yüksek Lisans Tezi). https://tez.yok.gov.tr/UlusalTezMerkezi/ adresinden 26.05.2021 tarihinde erişilmiştir.

Özcan, R., Aktamış, H. \& Hiğde, E. (2018). Fen bilimleri derslerinde kullanılan argümantasyon düzeyinin belirlenmesi. Pamukkale Üniversitesi Eğitim Fakültesi Dergisi, 43(1), 93-106. DOI: 10.9779/PUJE857.

Özkal, N. (2002). Sosyal bilgiler dersine yönelik tutum ölçeğinin geliştirilmesi. Eğitim ve Bilim, 27(124), 5255.

Öztürk, A. (2013). Sosyo-bilimsel konularla argümantasyon becerisi ve insan haklarına karşı tutum geliştirmeye yönelik bir eylem araştırması. (Yayınlanmamış Doktora Tezi). Çukurova Üniversitesi Sosyal bilimler Enstitüsü, Adana.

Polat, H. (2014). Atomun yapısı konusunda argümantasyon yönteminin ilköğretim 7. sını öğrencilerinin başarısı üzerine etkisi. (Yayınlanmamış Yüksek Lisans Tezi). İnönü Üniversitesi Eğitim Bilimleri Enstitüsü, Malatya.

Sadler, T. D. \& Fowler, S. R. (2006). A threshold model of content knowledgetransferfor socioscientific argumentation. Science Education, 90(6), 986-1004.

Sampson, V. \& Clark, D. B. (2008). Assessment of the ways students generate arguments in science education: Current perspectives and recommendations for future directions. Science Education, 92, 447-472.

Şekerci, A. R. (2013). Kimya laboratuvarında argümantasyon odaklı öğretim yaklaşımının öğrencilerin argümantasyon becerilerine ve kavramsal anlayışlarına etkisi. (Yayınlanmamış Doktora Tezi). Atatürk Üniversitesi Eğitim Bilimleri Enstitüsü, Erzurum.

Tabachnick, B. \& Fidell, L. S. (2015). Çok değişkenli istatistiklerin kullanımı. Ankara: Nobel Akademik Yayıncilık.

Torun, F. (2015). Sosyal bilgiler dersinde argümantasyon temelli ögretim ve karar verme becerisi arasındaki ilişki düzeyi. (Yayımlanmamış Doktora Tezi), Gazi Üniverstesi, Eğitim Bilimleri Enstitüsü, Ankara.

Torun, F. \& Şahin, S. (2016). Determination of students' argument levels in argumentation-based social studies course. Education and Science, 41(186), pp. 233-251.

Tuncel, S. T. (2016). Investigating the effects of science writing heuristic approach on eight grade students' achievement, metacognition and epistemological beliefs. (Yayınlanmamış Yüksek Lisans Tezi). Ortadoğu Teknik Üniverstesi, Sosyal Bilimler Enstitüsü, Ankara.

Ulu, C. \& Bayram, H. (2015). Argümantasyon tabanlı bilim öğrenme yaklaşımına dayalı laboratuar etkinliklerinin 7. sınıf öğrencilerinin kavram öğrenmelerine etkisi: Yaşamımızdaki elektrik ünitesi. Pamukkale Üniversitesi Ĕ̈itim Fakültesi Dergisi, 37, 63-77.

Uluçınar Sağır, Ş., Soylu, İ. \& Bolat, A. (2021). 7. Sınıf öğrencilerinin kuvvet ve enerji ünitesindeki argümantasyon seviyelerinin belirlenmesi. AJESI Anadolu Journal of Edcuational Sciences International, 11(1), 184-203.

Üstünel, H. H. \& Tokel, S.T. (2017). Teknoloji ile zenginleştirilmiş öğrenme ortamlarında öğrencilerin bilimsel argümantasyona rehberli öğrenme desteği sağlaması. Ömer Halisdemir Üniversitesi, İktisadi ve İdari Bilimler Fakültesi Dergisi, 10(1), 122-152. 